\title{
A summary of research results on pasture responses to fertiliser and lime in the South Island hill and high country
}

\author{
Jeff D. MORTON ${ }^{*}$, Jim R. MOIR ${ }^{2}$ and Derrick J. MOOT ${ }^{3}$ \\ ${ }^{1}$ MortonAg, 8 Deacon St, Christchurch 8025, New Zealand \\ ${ }^{2}$ Lincoln University, Soil Science Department, PO Box 85084, Lincoln 7647, Canterbury, New Zealand \\ ${ }^{3}$ Lincoln University, Plant Science Department, PO Box 85084, Lincoln 7647, Canterbury, New Zealand \\ *Corresponding author: mortonag1@gmail.com
}

\begin{abstract}
Early research found that sulphur (S) alone was required on less weathered Semi-Arid and Pallic soils, but $\mathrm{S}$ and phosphorus $(\mathrm{P})$ were required on more weathered and leached Brown soils. Sulphur was needed for legume growth before a response to $\mathrm{P}$ was measured on most soils, leading to the development of sulphur fortified superphosphate products. Later research determined the most effective particle size of elemental $\mathrm{S}$ in relation to frequency of application. More recent research showed that nitrogen $(\mathrm{N})$ fertiliser could enhance resident pasture growth and added $\mathrm{S}$ improved the response. Molybdenum (Mo) was found to be the only trace element lacking for pasture growth. More recent research has shown that using lime to alleviate soil aluminium $(\mathrm{Al})$ toxicity on acidic soils has allowed legumes to better establish and persist. Current gaps in data include; responses to $\mathrm{P}$ and $\mathrm{S}$ from legumes on easy slopes and shady aspects, S and lime on Pallic and Semi-arid soils on shady aspects, $\mathrm{P}$ and $\mathrm{S}$ requirements of pure legume swards, $\mathrm{N}$ for legume establishment, management to break down thatch, soil injection of lime and the use of test strips to detect lack of Mo. Such information can aid farmers in their selection of legume species and fertiliser and lime requirements.
\end{abstract}

Keywords: legumes, molybdenum, nitrogen, phosphorus, sulphur

\section{Introduction}

South Island hill and high country is loosely defined as those areas over $500 \mathrm{~m}$ altitude that make up the foothills and plains on inter-montane areas of the Southern Alps and other mountain ranges, plus the hill country nearer to the coast. These areas stretch from Marlborough in the north to Northern Southland in the south and encompass Central Otago and the McKenzie Basin. In the last decade, there has been an expansion in the development of unproductive land into improved pasture in the hill and high country of the South Island. This development has been caused by ownership by a younger generation of farmers, loss of traditional finishing country to dairy farming, which has meant more animals are finished on-farm, higher prices for fine wool and the freeholding of lower altitude land through tenure review. As part of this expansion, there has been a revival in the recognition of legume species as the generator of $\mathrm{N}$ into the soil and as a source of high nutrient value for grazing animals.

The purpose of this paper was to summarise the results from South Island hill and high country research and identify the areas where more information is required. The Te Anau basin has been excluded from this summary because most of its Allophanic soils, which are only unique to this part of the the South Island, have already been developed into improved pasture, and the results are not applicable to the majority of soils of sedimentary origin. This summary includes research that has been published in New Zealand pastoral scientific journals.

\section{Climate}

Mean annual rainfall ranges from $300-500 \mathrm{~mm}$ in Central Otago up to $2000 \mathrm{~mm}$ in the western fringes of the Southern Alps. Rainfall increases with altitude from east to west. Temperatures drop to zero in winter but can be as high as at least 30 degrees for short periods in summer, especially in areas with a Mediterranean-type climate, such as Central Otago.

\section{Soils}

The main factors that have formed soils in this area are time, climate and vegetation. The common parent (rock) materials are greywacke and schist. The SemiArid soils are weakly weathered and leached, Pallic soils moderately leached and Brown soils are more leached because leaching increases with altitude and rainfall. At higher rainfall, beech (Nothofagus spp.) forests with acid foliage can increase the leaching of nutrients through podzolisation. The influence of human activity is reasonably consistent for all soils, with a history of burning tussocks, but this has been less influential because of the relatively short duration of human settlement.

Table 1 shows the association between soil orders and environmental characteristics and farming history. 


\section{Summary of published results}

Where differences between treatments are stated as significant, this is at or above the $5 \%$ level of probability.

\section{Sulphur and sulphur $x$ phosphorus on legume-based pastures: Trials from 1950 to 1970}

Walker et al. (1957) conducted three sets of trials on Pallic and Brown soils in Canterbury hill country. Their aim was to measure the relative requirement of clover for sulphur (S) and phosphorus (P) and determine the optimal rate and the most effective form of S. On 10 sites with Pallic and Brown soils, there was a $30 \%$ response in clover vigour to $\mathrm{P}$ and on all but one site on the Banks Peninsula, where there would have been atmospheric return from sea spray, a further $50 \%$ response to $\mathrm{S}$. In the first year, on three separate sites near the Rakaia Gorge with an annual rainfall of 425 , 450 and $1000 \mathrm{~mm}$, there was a $39 \%$ response in total yield up to $50 \mathrm{~kg} \mathrm{~S} / \mathrm{ha}$ when applied as gypsum. Sulphur applied in the sulphate form as gypsum at $15 \mathrm{~kg} \mathrm{~S} / \mathrm{ha}$ resulted in a $49 \%$ higher clover yield compared to the elemental $\mathrm{S}$ in two further trials, and a $38 \%$ greater response with $20 \mathrm{~kg} \mathrm{~S} / \mathrm{ha}$ in another trial.

At three sites on Semi-Arid, Pallic and Brown soils in Central Otago sown with white clover and one site with lucerne, Ludecke (1960) reported 29-54\% responses in vigour to rates of 12.5 to $50 \mathrm{~kg} \mathrm{~S} / \mathrm{ha}$ over two years (supplied as gypsum) which was superior to elemental S applied on two of the sites. The response in vigour to $\mathrm{S}$ did not differ with rate of $\mathrm{P}$. Where annual rainfall increased from 550 to $700 \mathrm{~mm}$, Ludecke (1962) measured a $47 \%$ response in white clover vigour when elemental S was applied up to $50 \mathrm{~kg} / \mathrm{ha}$, with a greater response when $\mathrm{P}$ was applied as rainfall increased. This result was confirmed at another three Brown soil sites with annual rainfall of 800 to $1000 \mathrm{~mm}$ (Ludecke 1962). On two sites with Pallic and Semi-Arid soils in Central Otago, with white clover as the major legume, there was a $76 \%$ increase in DM production from up to $50 \mathrm{~kg} \mathrm{~S} / \mathrm{ha} / \mathrm{yr}$. Sulphur as gypsum increased yield more than fine elemental $\mathrm{S}$, which, in turn, was superior to coarse elemental S (Ludecke 1965).

These early trial results defined the role of $\mathrm{S}$ and $\mathrm{P}$ for legume growth, using chronosequences (Walker 1957; Ludecke 1960; 1962; 1965) and found that $S$ was generally deficient in all soil groups, regardless of time of formation, but $\mathrm{P}$ was only lacking in the older Brown soils at higher altitude which were more weathered and leached. Even on these soils, a response to P was only seen where adequate $\mathrm{S}$ had been applied. The other major finding was the greater effectiveness of a soluble, quickly available form of $\mathrm{S}$ over the more slowly available elemental $\mathrm{S}$ in these acutely deficient soils. This effect was more marked during the establishment and early growth of legumes, and was probably exacerbated by the absence of S-oxidising bacteria in the soil and the the lower plant availability of $S$ from the coarser particle size of the elemental S compared with gypsum.

\section{Trials from 1970 to 1990}

Douglas and Kinder (1975) carried out a series of complete S x P factorial trials at five sites with Pallic and Brown soils in North Otago. They measured a significant response of $38 \%$ to $\mathrm{S}$ in clover vigour. The response to $\mathrm{P}$ was greater as annual rainfall increased from 850 to $1300 \mathrm{~mm}$, especially for plant establishment. Only the site with highest rainfall had a significant S x P interaction in vigour. In a further series of S x P factorial trials at 23 sites in the Upper Waitaki and Hakataramea Valley (Douglas and Risk 1981), there was a significant response of $49 \%$ in clover vigour to $\mathrm{S}$ application at all sites, but the only response to $\mathrm{P}$ was observed for establishment on Brown soils with higher rainfall.

The development of the soil sulphate-S test in the 1970s, followed by organic and total S tests, made it possible to define the $\mathrm{S}$ status of soils in individual paddocks and farms which refined the understanding of what type and rate of S was required. Calibration of the soil sulphate-S test with pasture production generally showed that levels had to be $3 \mathrm{ppm}$ or less before a significant response was obtained (eg. Smith et al., 2004).

McIntosh et al. (1984) compared pasture production from over-sown clover and Maku Lotus on five sites in

Table 1 Soil orders and their environmental characteristics and farming history.

\begin{tabular}{lccll}
\hline Soil Order & Altitude $(\mathbf{m})$ & Annual rainfall $(\mathbf{m m})$ & Original vegetation & Farming history \\
\hline Semi-arid & $500-1000$ & $300-500$ & Fescue, silver and blue tussock & $\begin{array}{l}\text { Burning and grazing by sheep } \\
\text { and rabbits } \\
\text { Pallic }\end{array}$ \\
\hline $500-700$ & $500-1000$ & Fescue tussock & $\begin{array}{l}\text { Burning, over-sowing and } \\
\text { cultivation }\end{array}$ \\
Brown & $700-2000$ & $1000-1500$ & Snow tussock & Burning and over-sowing \\
Podzol & $1000-2000$ & $>1500$ & Bracken fern, beech forest & Burning and over-sowing \\
\hline
\end{tabular}


the East Otago uplands on Brown and Podzol soils with annual rainfall increasing from 470 to $1100 \mathrm{~mm}$, soil Olsen P ranging from $3-10 \mu \mathrm{g} / \mathrm{ml}$ and sulphate-S of 3-7 $\mathrm{ppm}$. They reported significant responses of $84 \%$ from over-sown clover up to $53 \mathrm{~kg} \mathrm{P} / \mathrm{ha} / \mathrm{yr}$ and $69 \%$ with applications of 13-20 kg P/ha/yr from Lotus. McIntosh et al. (1985) used a full factorial array of application rates of $\mathrm{S}$ and $\mathrm{P}$ and the form of $\mathrm{S}$ fertiliser at a further four sites of clover and lucerne-based pasture on two farms (average annual rainfall $435 \mathrm{~mm}$ ) in the Upper Waitaki Valley on Pallic and Brown soils with soil sulphate-S ranging from 1-3 ppm and Olsen $P$ from 6-23 $\mu \mathrm{g} / \mathrm{ml}$. They reported significant pasture production responses of $86 \%$ to $\mathrm{S}$ and found that superphosphate and molten mix $\mathrm{S}$ superphosphate were superior to coarse agricultural grade elemental forms in the first two years, but there was no difference in the third year. There was a greater response in pasture production to $\mathrm{P}$ from the Brown than the Pallic soils. At five sites oversown with clover in the South Canterbury foothills and the McKenzie Basin, McLeod (1974) reported a 56\% increase in pasture production from $185 \mathrm{~kg} / \mathrm{ha}$ of $18 \%$ $\mathrm{S}$ superphosphate applied annually or biennially over five years. On ten Otago high country acid soils (Olsen P 3-22 $\mu \mathrm{g} / \mathrm{ml}$, sulphate S 3-11 ppm), Floate et al. (1985) measured large responses in pasture production to $\mathrm{S}$ application from both Maku Lotus and white clover, but both species responded similarly to $P$.

Swanney et al. (1988) applied different particle sizes of elemental S at $50 \mathrm{~kg} \mathrm{~S} / \mathrm{ha}$ on a Pallic soil with annual rainfall of $1000 \mathrm{~mm}$ and a soil sulphate-S of $8 \mathrm{ppm}$. They found that particles less than $150 \mu \mathrm{m}$ were effective in the first year only, $150-500 \mu \mathrm{m}$ were effective in all three years and greater than $500 \mu \mathrm{m}$ were ineffective.

In these trials, the effect of weathering and leaching, according to soil formation time, on $\mathrm{S}$ and Prequirements was further confirmed using a toposequence approach in the Waitaki Basin and East Otago (Douglas and Kinder 1975, Douglas and Risk 1981). The results reported by McIntosh et al. $(1984 ; 1985)$ and Swanney et al., (1988) established that finer-ground elemental S was required for annual application and coarser ground forms performed best for less frequent applications.

On one of the two farms used by McIntosh et al. (1985), subsequent trials at four sites on Pallic soils were conducted (Boswell and Swanney 1991) applying a molten mix $\mathrm{S}$ superphosphate and superphosphate, which resulted in greater pasture production than coarser agricultural grade elemental S. When applied biennially, similar production was achieved from the fine elemental $\mathrm{S}$ at $50 \mathrm{~kg} / \mathrm{ha}$ compared with the coarser form at $100 \mathrm{~kg} / \mathrm{ha}$. After three years, the site on the sunny face was dominated by lucerne and by white clover on the shady site.

\section{Trials from 1990 to the present day}

For a lucerne sward at Omarama on a Pallic soil with initial soil sulphate-S levels of 6-7 ppm, there was no response to $\mathrm{S}$ in pasture production until the fourth year after application (Boswell 1997). Gypsum, screened elemental S with $42 \%$ less than particle size of $500 \mu \mathrm{m}$ and elemental $\mathrm{S}$ with particle size less than $150 \mu \mathrm{m}$ gave the highest pasture growth.

On a trial site at Mt John near Tekapo on a Pallic soil under annual rainfall of $820 \mathrm{~mm}$, superphosphate application depressed tussock and Hieracium growth while this increased with $\mathrm{N}$ application (Scott 2000a). The modelled optimal fertiliser rate was $250 \mathrm{~kg} / \mathrm{ha}$ of elemental S with a particle size of $2.2 \mathrm{~mm}$ diameter every five years (Scott 2000b). Annual application of both fine and granular elemental $\mathrm{S}$ resulted in significantly more pasture production than 4-yearly application (Scott et al., 2006).

At Mt Lindis on a Brown soil with annual rainfall of $700 \mathrm{~mm}$ and sulphate-S levels of $3 \mathrm{ppm}$, Craighead et al. (1990) found that, when applied once, superphosphate mixed with a finely ground product was a more effective form of $S$ than superphosphate and coarsely ground elemental S over a 3-year period. Sulphur bentonite prills were effective after 6 months from application. In a further four trials at Mt Lindis (three sites) and Wairau Valley, with soil sulphate-S levels of 2-3 ppm, Craighead and Metherell (2006) reported a similar result to the original work at Mt Lindis, whereby biennial application of S resulted in $22 \%$ more pasture production than triennial application.

In the 1970s and 1980s, the focus switched to further identification of the most effective particle sizes of elemental S according to the frequency of application (Swanney et al., 1988; Craighead et al., 1990; Boswell and Swanney 1991; Boswell 1997; Craighead and Metherell 2006). Sulphur bentonite prills, similar to the granulated elemental $\mathrm{S}$ products currently available, were as effective as superphosphate and wet mix $\mathrm{S}$ superphosphate manufactured by adding molten elemental S to superphosphate (Craighead et al., 1990, Craighead and Metherell 2006). In general, the lesser the frequency of application of elemental S, the coarser the fraction required, to an upper limit of $500-1000 \mu \mathrm{m}$.

One of the outcomes from this $\mathrm{S} \times \mathrm{P}$ and $\mathrm{S}$ research was the realisation that superphosphate contained more $\mathrm{P}$ and less $\mathrm{S}$ than was required by pasture on most hill and high country soils. Gypsum, as a source of S, was largely commercially unavailable. Therefore, in order to achieve the correct S:P ratios in fertiliser, more research on the supplementation of superphosphate with elemental S was carried out. The whole area of $\mathrm{S}$ and $\mathrm{P}$ requirements for pasture in the South Island hill and high country can be considered as adequate and well established. 


\section{Sulphur and sulphur $x$ nitrogen on legume- based and grass pasture}

At Mt Somers, on a Pallic soil with resident low fertility-demanding grasses, Vartha (1963) measured a significantly greater response in total DM production when $400 \mathrm{~kg} \mathrm{~N} / \mathrm{ha}$ was applied with either 20 or 100 $\mathrm{kg} \mathrm{S} /$ ha over four months. O'Connor and Vartha (1969) reported a similar $\mathrm{S} \times \mathrm{N}$ interaction in resident grasses on a Brown soil at Broken River in the Waimakariri Basin. On two farms with both a sunny and shady aspect at Omarama (Semi-arid soils) and Tarras (Pallic soils) with predominantly ryegrass/subterranean clover pastures, Smith et al. (2004) measured a significant response of $31 \%$ in total DM production with applications of up to $71 \mathrm{~kg} \mathrm{~N} / \mathrm{ha} / \mathrm{yr}$. There was a significant $9 \%$ response $(\mathrm{P}<0.10)$ to $10 \mathrm{~kg} \mathrm{~S} / \mathrm{ha} / \mathrm{yr}$ where soil sulphate-S levels were less than $3 \mathrm{ppm}$. There was only a significant $\mathrm{S} x \mathrm{~N}$ interaction for the sunny site at Tarras. In a glasshouse trial on Brown soil, Maxwell et al., (2012) reported that adventive annual clovers were more tolerant of low soil $\mathrm{S}$ than white and subterranean clover.

Even as far back as the 1970s the potential for N to increase the growth of unimproved and improved grasses and resident legumes was seen in a small number of trials (O'Connor 1961; Vartha 1963; O'Connor and Vartha 1969). This work expanded into the early 2000s, with research showing a greater effect of $\mathrm{P}$ on shady and easier slopes, where more legume was present, and $\mathrm{N}$ on sunny and steep slopes, where there were mainly resident grasses (Smith et al., 2004; Gillingham et al., 2007; 2008). On soils with low levels of plant-available $\mathrm{S}$, the yield response to $\mathrm{N}$ from grasses could be enhanced by the application of rapidly available $\mathrm{S}$.

\section{Phosphorus and phosphorus $x$ lime on legumes}

In glasshouse trials using high country soils, Davis (1981) reported that yield responses to P from white clover, Lotus corniculatus and lupins were similar. In another glasshouse experiment, Moir et al. (2016) demonstrated significant responses in yield from a suite of pasture legumes grown in an acidic high country soil to either $\mathrm{P}$ or lime. Large variations in yield response and optimum $\mathrm{pH}$ have been reported between species. Maxwell et al. (2013) measured yield responses to $\mathrm{P}$ from clover in the descending order of subterranean, haresfoot, white, suckling, cluster and striated species. On a Pallic soil at Tarras with a soil Olsen P level of $15 \mu \mathrm{g} / \mathrm{ml}$, Smith et al. (2014) did not measure any significant response to $\mathrm{P}$ from lucerne managed with all mown clippings removed. However, Scott and Maunsell (1981) measured a large significant response to $800 \mathrm{~kg} / \mathrm{ha} / \mathrm{yr}$ of superphosphate from white and red clover and lucerne on previously unfertilised tussock. These research results showed that the variation in $\mathrm{P}$ requirements depended on the initial available-soil $\mathrm{P}$ level and the type of legume sown.

\section{Nitrogen and nitrogen $x$ phosphorus on legume-based and grass pastures}

In three trials at Broken River, O'Connor (1961) measured large pasture production responses of 54\% when applying up to $400 \mathrm{~kg} \mathrm{~N} / \mathrm{ha} / \mathrm{yr}$ on ryegrass/white clover pastures, although clover growth was supressed in the second and third cuts after application. On flat land near Tekapo, Scott and Maunsell (1981) reported large significant responses in DM production when up to 345 $\mathrm{kg} \mathrm{N} / \mathrm{ha} / \mathrm{yr}$ was applied to a range of improved grasses. On border-dyke irrigated land in the McKenzie Basin, Scott et al. (1982) reported large significant responses in DM production when up to $1 \mathrm{t}$ superphosphate/ha and $200 \mathrm{~kg} \mathrm{~N} / \mathrm{ha}$ was applied to a range of improved grasses. Hall and Scott (1984) found that the application of 40 $\mathrm{kg} \mathrm{N} / \mathrm{ha}$ to over-sown white and red clover or Maku Lotus, with or without a mixture of improved grasses, increased total DM yields by $64 \%(22 \mathrm{~kg} \mathrm{DM} / \mathrm{kg} \mathrm{N})$ and yield contribution of the sown grasses by $25 \%$. At Mt John, Pollock (1989) reported that $\mathrm{N}$ encouraged the establishment of improved grasses over 3 years. From trials on sites with easy or steep slopes in the Awatere Valley and at Moeraki with soil Olsen P levels less than $12 \mu \mathrm{g} / \mathrm{ml}$, Gillingham et al. $(2007 ; 2008)$ measured significant pasture production responses to $\mathrm{N}$ and $\mathrm{P}$. These benefits were only seen on the steep slope in the Awatere Valley, but were evident for both $\mathrm{N}$ and $\mathrm{P}$ on both slopes in most years at Moeraki. Over four years in the Upper Teviot Basin near Roxburgh, Stevens et al. (2014) reported significant responses of $31 \%$ in pasture production when up to $100 \mathrm{~kg} \mathrm{~N} / \mathrm{ha} / \mathrm{yr}$ was applied from the second year onwards. Therefore, total pasture yield could be increased from the application of $\mathrm{N}$ fertiliser even at high rates of $400 \mathrm{~kg} / \mathrm{ha} / \mathrm{yr}$, but this could result in less legume growth from shading by grasses.

\section{Trace elements}

The only trace element that has been reported as lacking in South Island hill and high country for pasture growth requirements is molybdenum (Mo). The earliest evidence of pasture yield responses to Mo was reported by Davies (1952) near Outram on the Otago Plateau, and Holmes (1952) from Invermay Research Station. Lobb (1952) recommended application rates of up to $70 \mathrm{~g} / \mathrm{ha}$ of sodium molybdate from his work in North Otago on Pallic soils. Ludecke (1962) investigated eleven high country tussock sites in Central Otago and measured responses in legume vigour to Mo at only two sites on Podzol soils. At an initial soil pH of 5.5 on a Pallic soil at Invermay Research Station, Scott et al. (1963) reported a similar response in pasture production to the addition of $70 \mathrm{~g} / \mathrm{ha}$ of sodium molybdate or 
$3.75 \mathrm{t} / \mathrm{ha}$ of lime to increase soil $\mathrm{pH}$ to near 6.0. This demonstrated that a yield response could be obtained by increasing the availability of Mo from liming these soils. In an adjacent trial at Invermay, the maximum response in pasture production was measured at annual rates of 7 - $65 \mathrm{~g} /$ ha sodium molybdate over seven years (Scott 1963) and the general recommendation was to apply $56-70 \mathrm{~g} /$ ha every $4-5$ years. On a Brown soil with a soil $\mathrm{pH}$ of 4.9, Lowther and Adams (1970) reported no response in pasture production from the application of Mo. In a trial series that included one site at Hindon on the Otago Plateau on a Pallic soil and two sites with lucerne in Central Otago on a Pallic and Semi-arid soil, Morton and Morrison (1997) measured a DM response only when legume Mo was less than $0.1 \mathrm{ppm}$ for white clover and $0.5 \mathrm{ppm}$ for lucerne, and $\mathrm{N}$ content was less than $4.5 \%$ for both species. This research showed that a lack of Mo for legume growth could be measured from leaf analysis of Mo and $\mathrm{N}$ and remedied by the application of Mo every four to five years or by spreading lime.

\section{Lime}

Pasture DM production responses to lime varies in South Island hill and high country soils. At a low initial soil $\mathrm{pH}$ of 4.9 in a pot trial with a Brown soil, Lowther and Adams (1970) measured significant responses in legume inoculation and pasture production (94\%) from liming up to levels of $1.25 \mathrm{t} / \mathrm{ha}$. In contrast, in the Upper Teviot Valley on pasture dominated by lowfertility grasses at an initial soil $\mathrm{pH}$ of 5.1, Stevens et al. (2014) did not measure any response in production to lime, but did record an increase in pasture quality. In agreement, Moir and Moot (2010) failed to measure a significant response in pasture production to lime at an initial soil $\mathrm{pH}$ of 5.3 in a very low-yielding pasture on a stony soil in the Lees Valley. On the Otago Plateau on acid soils, Lowther (1980) reported that white and red clover required lime for establishment and growth but only for establishment for Maku Lotus. Floate et al. (1985) reported responses in pasture production to lime from white clover, but not Maku Lotus, on ten Otago high country acid ( $\mathrm{pH} 4.5-5.2$ ) soils. On an acid soil near Tekapo, with an initial soil $\mathrm{pH}$ of 5.1 and exchangeable $\mathrm{Al}$ of $8.9 \mathrm{ppm}$, Berenji et al. (2018) reported that production from white clover and Balansa clover, Maku Lotus and lucerne increased with lime application up to $4 \mathrm{t} / \mathrm{ha}$, but no response was measured from Russell lupins or Caucasian clover. At Omarama, Hendrie et al. (2018) reported significant responses of $44 \%$ in lucerne production when up to $2 \mathrm{t} / \mathrm{ha}$ lime was injected at 20-25 cm soil depth in the second year after application, at an initial soil $\mathrm{pH}$ of 5.3 in the top $75 \mathrm{~mm}$ of soil. In contrast there was no significant response in lupin yield.
With South Island hill and high country soils being inherently acidic, pasture production responses to lime were measured in some (eg. Lowther and Adams 1970) but not all trials (eg. Moir and Moot 2010; Stevens et al., 2015). Most of the measured pasture DM production responses to lime in this environment were more likely to be measured on deeper soils with a high legume content and toxic soil Al concentrations. There were large differences in requirements for lime application between legume species, depending on their tolerance to high soil Al levels.

\section{Conclusions}

On Semi-arid and Pallic soils, further increases in pasture production from $\mathrm{P}$ application were only achieved when $\mathrm{S}$ requirements were satisfied. On Brown and Podzol soils, both $\mathrm{S}$ and $\mathrm{P}$ were required for maximum pasture production. Where initial soil $\mathrm{S}$ levels were low in these soils (sulphate-S levels < $3 \mathrm{ppm}$ ), the immediately available form of sulphate-S in superphosphate was required. However, when $\mathrm{S}$ requirements for optimal pasture growth were greater than $\mathrm{P}$ requirements, elemental $\mathrm{S}$ needed to be added to superphosphate. Finely-ground elemental $\mathrm{S}(<0.5$ $\mathrm{mm}$ particle size) was required where $\mathrm{S}$ was applied annually, but coarser ground elemental S (up to $1 \mathrm{~mm}$ particle size) was effective for less frequent applications. The application of $\mathrm{N}$ fertiliser (up to $400 \mathrm{~kg} \mathrm{~N} / \mathrm{ha} /$ yr) resulted in large increases in pasture production from grass-dominant swards, and this response could be enhanced by the application of S. For Mo, legume growth responses on hill and high country soils depends on the Mo and $\mathrm{N}$ concentrations in plant tissue. On these acidic soils, which often have toxic exchangeable Al levels above $5 \mathrm{ppm}$, lime is required to increase soil $\mathrm{pH}$ to 5.5 for best legume establishment and growth, but this depends on soil type, legume content of the sward and the concentration of A1 and the tolerance of the legume to soil $\mathrm{Al}$.

\section{Future research requirements}

The terrain of the hill and high country according to the gradient of slopes and aspect (sunny or shady) can cause differences in pasture production and composition. This variation offers the opportunity to differentially apply $\mathrm{P}$ and $\mathrm{S}$ fertiliser and lime to areas which grow more legume on easy slopes and shady aspects with greater soil moisture status to maximise returns (Gillingham et al., 2007; 2008). Most of the research on variable and differential application of $\mathrm{P}$ and $\mathrm{S}$ has been carried out in hill country in the North Island. With both major fertiliser companies having planes equipped to deliver to more difficult terrain, there is a case for more of this work to be done on P and S-responsive Brown soils in lower rainfall regions in the South Island. The 
steeper hill country on Semi-Arid and Pallic soils have a much greater requirement for $\mathrm{S}$ rather than $\mathrm{P}$, so the same approach may be used to differentially apply fine elemental S mixed with lime as a carrier to the shady aspects, which are able to grow more legume, especially in the spring. A relevant research programme should investigate the optimal rates of $\mathrm{S}$ and ratios of $\mathrm{S}$ :lime for increased legume growth and targeted, costeffective lime/S products.

Regarding nutrient levels from pastures, the establishment of pure or mixed white and red clover swards for finishing of stock has been carried out successfully on many properties. Lime and fertiliser $\mathrm{P}$ and $\mathrm{S}$ have been applied at standard rates for grass/ clover swards because there has been limited research carried out for clovers alone. The poorer ability for legumes to extract nutrients from the soil, compared with grasses, could be offset by the lack of competition from the grasses, resulting in less or more nutrients being required. More research is needed to help clarify this situation.

When sown into soils with very low total soil $\mathrm{N}$ levels in hill and high country, legumes may benefit from a low rate of fertiliser $\mathrm{N}$ to boost establishment, early growth and survival. Trial work to examine this hypothesis would show whether $\mathrm{N}$ or $\mathrm{P}$ or $\mathrm{N}$ and $\mathrm{P}$ at sowing is economically viable. Much of the undeveloped hill and high country soils have a thick layer of live and dead thatch derived from excessive growth of browntop and other resident species which restricts the establishment of over-sown legume species. Larger scale research needs to be carried out on the possible treatments to break this down, including herbicide, grazing and treading management as well as the use of nitrogen fertiliser.

Acid soils in hill and high country have high levels of exchangeable Al that inhibit rhizobial activity and nodule and root growth. When lime is required, especially in areas distant from any quarry, the economic return can be low to marginal. Soil exchangeable Al concentrations have been shown to be variable on a spatial scale. If they could be correlated with landscape or soil factors, this would allow ground-applied lime to be more efficiently used. The potential for lime to be injected into the deeper soil layers where Al levels are higher has been demonstrated on two hill and high country sites (Hendrie et al., 2018). Expansion of the research on to more sites would lead to more knowledge and confidence in extending the results to a farm scale.

There is an opportunity to use known research results to develop extension packages for legume introduction into the hill and high country. Possibilities include a decision tree that uses soil nutrient, $\mathrm{pH}$ information and climatic data to predict the most cost-effective legume choice in combination with economically optimal rates of fertiliser and lime. There is considerable debate around the extent of the requirement for Mo in hill and high country. The sampling of clover and interpretation of Mo and $\mathrm{N}$ content can be time-consuming and difficult, especially if the clover has been hard-grazed. Another possible method of diagnosis is the use of test strips to assess the visual response in legume vigour to Mo, and these responses could be correlated with clover analysis for calibration over a range of sites.

\section{ACKNOWLEDGEMENTS}

This work was funded by the Fertiliser Association of New Zealand. The Beef and Lamb Hill Country Futures programme is also acknowledged for the contribution of time from the co-authors.

\section{REFERENCES}

Berenji S; Mills A.; Moir J.L.; Pollock K.M.; Murray W.; Murray E.; Moot D.J. 2018. Dry matter yield of six legume species in response to lime over 3 years at Glenmore Station, McKenzie Basin. Journal of New Zealand Grasslands 80: 81-87. https://doi. org/10.33584/jnzg.2018.80.338.

Boswell C.C.; Swanney B.J. 1991. Comparison of the long term effects of different sulphur fertilisers on legume pasture production on a toposequence of North Otago soils, New Zealand. New Zealand Journal of Agricultural Research 34: 95-104. https:// doi.org/10.1080/00288233.1991.10417798.

Boswell C.C. 1997. Dryland lucerne responses to elemental sulphur of different particle sizes applied at different rates and frequencies in North Otago, New Zealand. New Zealand Journal of Agricultural Research 40: 283-295. https://doi.org/10.1080/0028 8233.1997.9513248.

Craighead M.D.; Burgess W.B.; Clark S.A.; Duffy R.G. 1990. Development of sunny-facing high country using different forms of sulphur fertiliser. Proceedings of the New Zealand Grassland Association 52: 203206. https://doi.org/10.33584/jnzg.1990.52.1947.

Craighead M.D.; Metherell A.K. 2006. The impact of the form and frequency of sulphur on pasture yield and composition in South Island high country. Proceedings of the New Zealand Grassland Association 68: 361-367. https://doi.org/10.33584/ jnzg.2006.68.2618.

Davies E.B. 1952. Molybdenum research in New Zealand. Proceedings of the New Zealand Grassland Association 14: 182-191. https://doi.org/10.33584/ jnzg. 1952.14.977

Davis M.R. 1981. Growth and nutrition of legumes on a high country yellow-brown earth subsoil. New Zealand Journal of Agricultural Research 24: 321332. https://doi.org/10.1080/00288233.1981.10423 393 
Douglas J.A.; Kinder J.W. 1975. Factors limiting the improvement of tussock grasslands from $850-1300 \mathrm{~m}$ altitude in the semi-arid zone of North Otago, New Zealand. New Zealand Journal of Experimental Agriculture 3: 127-133. https://doi.org/10.1080/030 15521.1975.10425788

Douglas J.A.; Risk W.H. 1981. Soil fertility studies in North Otago. I. The effects of phosphorus, sulphur and molybdenum on clover growth on a range of soils. New Zealand Journal of Experimental Agriculture 9: 47-55. https://doi.org/10.1080/03015 521.1981.10427802

Floate M.J.S., McIntosh P.D., Risk W.H., Enright P.D., Smith L.C. 1985. Effects of fertilisers and environment on Lotus production on high country acid soils in Otago. Proceedings of the New Zealand Grassland Association 46:111-118. https://doi. org/10.33584/jnzg. 1985.46.1685

Gillingham A.G.; Morton J.D.; Gray M.H. 2007. Pasture responses to phosphorus and nitrogen fertiliser on East Coast hill country: total production from easy slopes. New Zealand Journal of Agricultural Research 50: 307-320. https://doi. org/10.1080/00288230709510299.

Gillingham A.G.; Morton J.D.; Gray M.H.; Roberts A.H.C. 2008. Pasture responses to phosphorus and nitrogen fertilisers on East Coast hill country. 3. Production from steep slopes. New Zealand Journal of Agricultural Research 51: 425-438. https://doi. org $/ 10.1080 / 00288230809510472$.

Hall I.R.; Scott R.S. 1984. Effects of nitrogen on oversown tussock grasslands. New Zealand Journal of Experimental Agriculture 13: 285-288. https://doi. org/10.1080/03015521.1985.10426095

Hendrie D.L.; Moir J.L.; Stevens E.J.; Moot D.J. 2018. Soil $\mathrm{pH}$, exchangeable aluminium and legume yield responses to deep-placed lime at Omarama Station. Journal of New Zealand Grasslands 80: 137-143. https://doi.org/10.33584/jnzg.2018.80.341.

Holmes J.B. 1952. Molybdenum responses at Invermay. Proceedings of the New Zealand Grassland Association 14: 198-201. https://doi.org/10.33584/ jnzg.1952.14.979

Lobb W.R. 1952. Molybdenum responses in North Otago. Proceedings of the New Zealand Grassland Association 14: 192-197. https://doi.org/10.33584/ jnzg.1952.14.983

Lowther W.H.: Adams A.F.R. 1970. The interaction of lime and phosphorus on the nodulation and growth of white clover. New Zealand Journal of Agricultural Research 13: 252-262. https://doi.org/10.1080/00288 233.1970.10425398

Lowther W.H. 1980. Establishment and growth of clovers and lotus on acid soils. Proceedings of the New Zealand Grasslands Association 8: 131-138. https://doi.org/10.1080/03015521.1980.10426247

Ludecke T.E. 1960. Improvement of low altitude tussock country in Central Otago. Proceedings of the New Zealand Grassland Association 22: 96-110. https://doi.org/10.33584/jnzg.1960.22.1116

Ludecke T.E. 1962. Formulation of a rational fertiliser programme in tussock country. Proceedings of the New Zealand Grassland Association 24: 29-41. https://doi.org/10.33584/jnzg.1962.24.1153

Ludecke T.E. 1965. Further aspects of sulphur nutrition of legumes. Proceedings of the New Zealand Grassland Association 26: 129-139. https://doi. org/10.33584/jnzg.1965.27.1204

Maxwell T.M.R.; Moir J.L.; Edwards G.R. 2012. Sulphur and lime response of four annual adventive clovers grown in a New Zealand high country soil under glasshouse conditions. New Zealand Journal of Agricultural Research 55: 47-62. https://doi.org/1 0.1080/00288233.2011.643904

Maxwell T.M.R.; Moir J.L., Edwards G.R. 2013. Phosphorus response and efficiency of four annual adventive clovers grown in a New Zealand high country soil under glasshouse conditions. New Zealand Journal of Agricultural Research 56: 203214. https://doi.org/10.1080/00288233.2013.809775

McLeod C.C. 1974. Fertiliser responses in South Canterbury tussock country. Tussock Grassland and Mountain Land Institute Review 28: 19$30 . \quad$ https://agris.fao.org/agris-search/search. do?recordID=US201303176265

Moir J.L.; Moot D.J. 2010. Soil pH, exchangeable aluminium and lucerne yield responses to lime in a South Island high country soil. Proceedings of the New Zealand Grassland Association 72: 191-196. https://doi.org/10.33584/jnzg.2010.72.2788

Moir J.L., Jordan P, Moot D.J., Lucas R. 2016. Phosphorus response and optimum $\mathrm{pH}$ ranges for twelve pasture legumes grown in an acid, upland New Zealand soil. Journal of Soil Science and Plant Nutrition 16: 4338-460. http://dx.doi.org/10.4067/ S0718-95162016005000038

Morton J.D.; Morrison J.D. 1997. Molybdenum requirements of pasture. In: Proceedings of the New Zealand Fertiliser Manufacturers Research Conference: 18-31.

McIntosh P.D.; Enright P.D.; Sinclair A.G. 1984. Fertilisers for Lotus and clover establishment on a sequence of acid soils on the East Otago uplands. New Zealand Journal of Experimental Agriculture 12: 119-129. https://doi.org/10.1080/03015521.198 4.10421421 .

McIntosh P.D.; Sinclair A.G.; Enright P.D. 1985. Responses of legumes to sulphur and phosphorus fertilisers on two toposequences of North Otago soils, New Zealand. New Zealand Journal of Agricultural 
Research 28: 505-515. https://doi.org/10.1080/0028 8233.1985.10417996.

O'Connor K.F. 1961. Nitrogen and grassland production in the mid-altitude zone of Canterbury, New Zealand. I. The effects of different levels of nitrogen fertiliser on herbage and nitrogen levels of cultivated pastures. New Zealand Journal of Agricultural Research 4: 686-697. doi.org/10.1080/00288233.1961.10431625

O'Connor K.F.; Vartha E.W. 1969. Responses of grasses to sulphur fertilisers. New Zealand Journal of Agricultural Research 12: 97- 118. https://doi.org/10 $.1080 / 00288233.1969 .10427081$

Pollock K.M. 1989. Grass establishment and performance on a high country soil fertilised with nitrogen. New Zealand Journal of Agricultural Research 32: 7-15. https://doi.org/10.1080/0028823 3.1989.10423471.

Scott D.; Maunsell L.F. 1981. Pasture irrigation in the McKenzie Basin. 1. Species comparison. New Zealand Journal of Experimental Agriculture 9: 279290. https://doi.org/10.1080/03015521.1981.10425 426.

Scott D.; Clifford P.T.P; Archie W.J. 1982. Pasture irrigation in the McKenzie Basin 2. Yields on a shallow outwash soil. New Zealand Journal of Experimental Agriculture 10: 129-132. https://doi.or g/10.1080/03015521.1982.10427856

Scott D. 2000a. Sustainability of New Zealand high country pastures under contrasting development inputs 5. Nutrient pools and balances. New Zealand Journal of Agricultural Research 43: 415-438. https:// doi.org/10.1080/00288233.2000.9513440

Scott D. 2000b. Sustainability of New Zealand high country pastures under contrasting development inputs. 6. Fertiliser efficiency. New Zealand Journal of Agricultural Research 43: 525-532. https://doi.org /10.1080/00288233.2000.9513449

Scott D.; Robertson J.S.; Hoglund J.H. 2006. Considerations in low fertiliser rate application in the high country. New Zealand Journal of Agricultural Research 49: 59-65. https://doi.org/10.1080/002882 33.2006.9513694
Scott R.S. 1963. Long-term studies of molybdenum applied to pasture. III. Rates of molybdenum application in relation to pasture production. New Zealand Journal of Agricultural Research 6: 567-577. https://doi.org/10.1080/00288233.1963.10420013

Scott R.S.; Cullen N.A.; Davies E.B. 1963. Longterm studies of molybdenum applied to pasture. I. The effects of molybdenum and lime and their interaction. New Zealand Journal of Agricultural Research 6: 538-555. https://doi.org/10.1080/00288 233.1963.10420011

Smith L.C.; Morton J.D.; Trainor K.R.; Catto W.D. 2004. Application of nitrogen and sulphur to sunny and shady aspects on South Island dry hill country. Proceedings of the New Zealand Grassland Association 66: 41-48. https://doi.org/10.33584/ jnzg.2004.66.2557.

Smith L.C.; Trainor K.D.; Morton J.D. 2014. Nutrient requirements for irrigated lucerne in Central Otago. Proceedings of the New Zealand Grassland Association 76: 97-104. https://doi.org/10.33584/ jnzg.2014.76.2966.

Stevens DR, Thompson BR, Catto WD, Trainor KR 2014. Is nitrogen fertiliser an economic option in hill country? Proceedings of the New Zealand Grassland Association 76: 149-154. https://doi.org/10.33584/ jnzg.2014.76.2953.

Swanney B.; Boswell C.C.; Enright D.P.; Sinclair A.G. 1988. A comparative field evaluation of some sulphur fertiliser materials. New Zealand Journal of Experimental Agriculture 16: 183-192. https://doi.or g/10.1080/03015521.1988.10425637.

Vartha E.W. 1963. The effects of different levels of nitrogen and sulphur on the yield and composition of tussock grassland. New Zealand Journal of Agricultural Research 6: 47-55. https://doi.org/10.1 080/00288233.1963.10419320

Walker T.W. 1957. Sulphur responses on pastures. Proceedings of the New Zealand Grassland Association 19: 117-125. https://doi.org/10.33584/ jnzg.1957.19.1069 